\title{
Interreligious Dialogue and Politics in Revolutionary Egypt
}

\author{
Henrik Lindberg Hansen
}

\begin{abstract}
This article analyses the socio-political dynamics of religious belonging in Egyptian society prior to the revolution and how these have been carried into the revolutionary flux with a focus on official dialogue. Official dialogue, it is argued, is a dialogue form specific to Egyptian society and politics used as a way of negotiating interreligious relations and political ties. First the Egyptian concept of official dialogue as a socio-political phenomenon will be analysed applying theories from sociology and political science, followed by an analysis of how interreligious relations and official dialogue was influenced by the upheaval in socio-political structures following the 2011 revolution.
\end{abstract}

The article focuses on one type of dialogue in Egypt, official dialogue, and its relation to society and politics to discuss the influence of the revolution on Muslim-Christian relations. ${ }^{1}$ The term official dialogue is an in vivo concept, i.e. a concept taken from the field analysed, and as such the article endeavours to detail what the term encompasses in Egypt. The meeting of leaders representing different religious communities at holidays or connected to sectarian incidents is in Egypt often termed official dialogue by the participants, the media and in the general dialogue environment. The meetings often include representatives of political, police and military authorities, highlighting the political significance of the meetings. As this article ventures to detail, the practice of official dialogue is built on the Egyptian societal structures often termed 'clientelism', where leaders (religious and otherwise) of disparate national and local networks gain political influence by representing their group towards or in opposition to the ruling national entity. As such, the article builds on theories of clientelism, as developed by for example Nazih N. Ayubi and Holger Albrecht, as well as Social Movement Theory as described by Salwa Ismail, Diane Singerman and Carrie Rosefsky Wickham. It

\footnotetext{
${ }^{1}$ Currently in Egypt the term "revolution" is juxtaposed to the term "coup" in the discussion of the legitimacy of the removal of the Muslim Brotherhood from power in 2013. I will use the term "revolution" here for both the 2011 and the 2013 events, but without choosing sides in the ongoing struggle between Islamists and the military; the term will signify the fact that mass demonstrations somehow prompted the early termination of the ruling entity.
} 
should be noted that there are a number of other dialogue types practised in Egypt, such as diapraxis and academic dialogue (Hansen 2015), but these will not be the focus of the article.

Interviews in 2009-10 and again in 2013 with people working in the field of dialogue in Egypt have built an understanding of the practice of official dialogue, and how it is related to the societal dynamics of Egypt. The interviews were done among people working with official dialogue from the Muslim Azhar University and the Coptic Orthodox Church, as well as people in opposition to the idea of official dialogue as the negotiation of informal political relations from the Muslim Brotherhood, critical voices from the Azhar and the Coptic Orthodox Church and people from minority Churches and the NGO environment. ${ }^{2}$ It is argued that official dialogue is a tool to establish, consolidate or negotiate relations between societal groups defined by religion as well as socio-political belonging. Theories of clientelism and social movement describe how informal politics and networks define social relations and how they are negotiated in Egyptian society, and have been found to correspond very well with the analysis of official dialogue. The article therefore starts by describing theories of clientelism and social movements and how these dynamics are part of politics and religion in Egyptian society, to provide a basis for understanding official dialogue as a tool in the informal politics of Egyptian society. This is followed by a description of the socio-political setting followed by the 2011 revolution, pertinent to Christian-Muslim relations. The article then moves on to detail official dialogue and how it functions on the local as well as the national level. Finally, it is argued that official dialogue has been a tool of the Coptic Orthodox Church in the renegotiation of Egyptian society following the 2011 revolution, to establish and consolidate relations with the changing political powers. This has been especially necessary, as the revolution opened the question of the legitimacy of Christians having a voice in the informal politics of Egypt, as will be argued.

Clientelism, social networks and religion in Egypt before the 2011 revolution

In this article I argue that there was a discourse of official dialogue in Egypt in the time of study, which was highly dependent on the sociopolitical structures. Religion delimited social groups, where people

2 The article is based on my experience working with dialogue in Egypt, existing literature on Egyptian society, politics, and religion, participatory observation, and qualitative interviews. The interviews were open-ended conversations controlled by the interviewee, but held within topics by the interviewer. The focus was on a total of 29 interviews. The interviewees were either working explicitly with dialogue, or people who influenced the interreligious discourse in Egypt. 
found belonging and built their lives, which enabled the leadership of these communities to negotiate their social influence to the benefit of the group. To develop this, it is first needed to briefly address the socio-political dynamics that official dialogue built on.

Egyptian politics before the revolution in 2011 was marked by the fact that citizens were dependent on societal groups to build their livelihoods and for belonging - rather than expecting a state to guarantee their lives. This led sociologists and political scientists to describe Egyptian society as heavily dependent on corporatism, clientelism, paternalism, and other concepts emphasizing informal networks both horizontally among for example families, work communities, or local neighbourhoods and vertically ideally linking the elite of the country to the less fortunate through chains of dependency and favours (Ayubi 2006; Singerman 1997; Ismail 2006). ${ }^{3}$ The way to maintain power by the state was then to co-opt groups by tying their prosperity to the prosperity of the state. In the everyday language of Egyptians the concept of wasta, connections (Singerman 1997, 164), was used to denote a social glue equivalent to clientelism (Albrecht 2007, 21 and 52). Apart from the clientelist structures, the coercive abuse of power also pushed people to look for security and meaning in their local networks; networks which often were determined by and strengthening religious demarcation of societal groups.

As the divide between the elite and the poor in Egyptian society grew, the millions not cared for by the state turned to their local networks to secure their livelihoods. This was the case for many Muslims who felt their daily lives threatened, rather than protected by the regime. These turned to their local networks to secure their lives through, for example, job opportunities, fair trials by local customary judges outside the state judicial system, and loans (Ismail 2003; Wickham 2002, 153; Singerman 1997). This was often centred on the local mosques and the growing number of NGOs connected to these, leading to an amorphous Islamic movement with a focus on social justice by providing what many felt the regime should have provided (Sullivan and Abed-Kotob 1999). The growing use of religion to delimit societal belonging also influenced the more affluent middle class of Egyptian society. This part of society led relatively secure lives and often had less interest in showing their Islamic orthodoxy through political action. Following the trend of adopting Islamic legitimating of their lives, they instead applied it to their consumption. This was evident when people bought Islamic elevators reciting the

\footnotetext{
3 Concepts such as clientelism and paternalism are to some derogative, as they feel it only applies to pre-modern societies. This is, however, not the case (Abercrombie and Hill 1976, 413; Ayubi 2006, 169), modernity and clientelism are not contradicting terms (Lemarchand 1972) as they partake in most modern societies. Furthermore, clientelism is not a necessary part of a stable Egyptian culture (Ayubi 2006, 168), but rather a significant part of the contemporary construction of a society such as the Egyptian.
} 
Qur'an, Muslim fridges, or Islamic nail polish, highlighting themselves as good believers through their consumption (Abdelrahman 2004). The growing use of Islam as political and social legitimating had the secondary effect that many Christians felt that they did not belong to the same extent as the majority group of believers, and this alienated Christians from their compatriots.

The local networks were not unified, but scattered all over Egypt with some or no affiliation with more organised national groups. The Muslim Brotherhood (a conservative organisation, focussing on Islamic pietism and social justice to the improvement of society) had a special status, as they were the only real opposition to the regime and the major Islamic point of entry into political life. This made the Muslim Brotherhood the obvious choice for a person from the Islamic movement with political aspirations for example in the trade unions or parliament (Wickham 2002). As the co-optation of these local networks were central to the power base of the regime, the political battles were more often fought here through relation-building (based on clientelism), than through political struggle for votes in parliament. The description of the local networks furthermore explains the continued influence of the Muslim Brotherhood as rooted in a very dynamic, scattered and diversified pattern of local networks, despite repeated attempts of the regime to uproot the organisation.

Christians, not partaking in the Muslim identity of many of the social networks, sought networks according to their own religious belonging. The Coptic Christians expected the Church to provide them, what the Muslim social networks provided their compatriots sustaining the system of patronage (Sedra 1999, 228; M. Guirguis and van Doorn-Harder 2011, 156). According to Hassan (Hassan 2003, 152),

In most dioceses, the relationship between individual and church is not just pastoral but resembles a citizen-state relationship. Even though his relationship to his church does not carry with it the same element of compulsion as does the state-citizen counterpart, the demands made by a Copt on his church are similar. He expects it to not only cater to his spiritual needs but also to help him with educational, occupational, housing, and medical problems.

The Coptic Orthodox Church was a top-down controlled institution (M. Guirguis 2012; Galal 2009, 242; Vogt and van DoornHarder 2004, 145; Abu-Nimer, Khoury, and Welty 2007, 147), enabling the Church leaders to represent the majority of Coptic Christians in political matters of concern to the Copts. Clientelism was for example found in the cooperation between the former president Mubarak and the late Pope Shenouda III, where relations with the President for example would provide direct access between 
bishops and governors during tensions between Muslims and Christians in the governorates. To reciprocate the Pope would for example actively push for Copts to vote for Mubarak, which was especially obvious during the 2005 elections (Galal 2009, 222). This was essential to what will be described as official dialogue.

The political context of official dialogue following the 2011 revolution

While the 2011 revolution did not change much in terms of the political system and left the clientelist system intact (Aoudé 2013), it did renegotiate who was in power (Wickham 2013, 154). This led to a struggle especially between the Muslim Brotherhood and the Islamist movement on the one side, and the military and the traditional system on the other side. Pertinent to this article, is how the revolutionary flux influenced the understanding of the role of Christians in Egyptian society. The Christians as central to the discourse of national unity became a signifier in the political positioning of various other groups vying for political power, and this heightened the discussion of Christian legitimacy in the end producing a number of dialogue initiatives as well as escalating incidents. To discuss dialogue in the revolutionary period, it is therefore needed to briefly touch upon the revolutionary renegotiation of the political scene.

As explained in the beginning of the article, Egyptian politics under the rule of Mubarak was defined by the negotiation of power between the regime and different groups often delimited by religion. In brief; the Azhar, the Coptic Orthodox Church, and the Muslim Brotherhood were inside the definition of Egyptian national community, where they had each their socio-political role. The Mubarak regime was in power supported by the Azhar administration (Soliman 2011, 56 and 65). The Muslim Brotherhood was the opposition, and recognised (in practice, not rhetoric) as such by the regime as they were too influential to just brush aside (Albrecht 2007, 81; Scott 2010, 49). The Christians, especially the Coptic Church, had their own community within the national community that gained societal position by maintaining positive relations to the regime (Hassan 2003). These different groups consequently all had their positions and roles within the circle of national community (which defines the societal order): there was a hegemonic socio-political order, which allowed its people and groups to act and predict the actions of the others (Laclau 2007). Outside the circle of national community, there were a number of smaller groups, the ones of interest here being the more radicalised Islamist groups. Before the revolution much of the criticism of Christians being part of the legitimate societal order would come from groups outside the order. With the revolution, the hegemonic order of society was dissolved and 
the public debate about the weaker societal positions was opened for debate: as Egyptian societal positions were renegotiated, the position of minorities was unstable and open for discussion. This was especially the case for the Christians, as they held a key position in the discourse of national unity, as will now be argued.

With the revolution the position of Christians became a signifier or 'bargaining chip' in the positioning of other groups (L. Guirguis Forthcoming). Those who accepted Christians as part of national community were opposed to other positions, where Christians were not accepted as members of national community. This was already a discussion before the revolution, but most often not accepted within the legitimate political circle that defined who belonged to the national community ${ }^{4}$ with the revolution the circle of legitimacy itself was renegotiated and this allowed for the question of the societal position of the Christians to enter the debate to a larger extent. The societal position of the Christians was, however, not only visible in this more negative debate about how inclusive a Muslim state can be, but Muslim-Christian unity was also a powerful political symbol in protests and demonstrations: the slogan 'Muslims and Christians together' was used since the 1919 revolution to signify a unified Egypt against an oppressor, a slogan that only could be used meaningfully if there were Christians present at the demonstrations. The Copts as a symbol of national unity was also used by the military after the 2013 revolution when the commanding officer announced that power was taken from the Muslim Brotherhood flanked by the Grand Sheikh of the Azhar and the Coptic Pope - and again during the presidential elections in 2014, where the Pope openly backed the military candidate for presidency, Abdul Fatah Saeed Hussein Khalil el-Sisi.

During the 2011 revolution, scenes were reminiscent of the 1919 revolution with Muslims and Christians demonstrating against oppression in unity for the sake of their common nation. The incidents following the revolution did, however, leave many Christians fearing for their future in Egypt as Christians (Galal 2012, 45). The period following the 2011 revolution saw a number of negative incidents against Christians, based on the socio-political climate. The most prominent of the negative incidents happened in October 2011 in Cairo, where armoured military trucks rammed into Copts demonstrating an incident in a village, and the interim military government asked civilian Muslims to come to the aid of the military in the media (Iskander 2012, 174; McNamara et al. 2014). Especially following the military ousting of the Muslim Brotherhood President in 2013, there was an explosion of attacks where Coptic Churches and shops became the focal point of Islamist frustrations (McNamara et al.

4 Laure Guirguis (forthcoming) argues that this was already the case during the 2005 elections and not diminished after the 2011 revolution. See also Iskander $(2012,15)$. 
2014), as these were seen as promoting the military regime. According to Human Rights Watch at least 42 churches in different governorates were attacked in August 2013, of which about 37 were damaged or burned (Human Rights Watch 2013).

The 2013 revolution changed the conditions for MuslimChristian relations: the Muslim Brotherhood was pushed into a defensive camp of Islamists also comprising radical elements, when the Muslim Brotherhood President was deposed by the military following massive demonstrations against the rule of the Brotherhood, while the Christians were on the side of the (also Muslim) liberals and the military. The political dichotomisation following the 2013 revolution highlighted the Christians as a political and religious opponent to the Islamist movement spearheaded by the Muslim Brotherhood. This left the Christians salient as a focal point for Islamist frustrations after the military deposing the elected Islamist president and reverting the Islamist position to the times before the 2011 revolution, where they were unable freely to participate in the political process. At the same time as the post-2013 situation created obvious enemies for the Christians in the Islamists, it also provided obvious allies in the (also Muslim) liberals and the military (Hulsman 2013). Most Copts voted against the Muslim Brotherhood in the 2012 elections and sided with the military in the 2013 revolution; this muffled some of the more moderate voices in the Muslim Brotherhood and legitimised that the more radical voices from the Islamist movement targeted Christians and Christian property and churches. Many Muslim Brotherhood leaders believed that the best way to maintain political legitimacy was through non-violent demonstrations. This did, however, not stop leading members of the Muslim Brotherhood from delivering hate speeches against their political opponents, including the Christians, undoubtedly leading to violence on the ground (Human Rights Watch 2013), as was obvious from an Egyptian Muslim interviewee:

The military is not supposed to be vengeful and randomly arrest people because of their political affiliation. But the Muslim Brotherhood is no better with their hate speeches against their political opponents; they might not be overtly violent as an organisation and we cannot generalise that all their members resort to violence, yet the leaders of the Muslim Brotherhood are provoking the Islamist movement and pushing laymen to violence in the name of defending their "religion".

It is difficult for the average Egyptian to make out who advocated violence and who peaceful demonstrations in the revolutionary turmoil, and many questioned the political legitimacy of the Islamic bloc and the Muslim Brotherhood following the 2013 revolution.

Before describing the influence of the revolutionary period on dialogue in Egypt, it is first needed to analyse, what official dialogue as a specifically Egyptian phenomenon. While there are a number of 
different types of dialogue in Egypt, official dialogue is partaking in the socio-political dynamics of the country. Official dialogue has played a significant role in the revolutionary period, as will be described later, after an introduction to the concept as it was used in Egypt in the period of study, before the revolution.

\section{Official Dialogue at the local level}

Official dialogue as a way of negotiating Christian-Muslim relations in Egypt was present on the local as well as the national level during the time of my work and fieldwork. I stayed in a village close to Minya in Upper Egypt for a combined three months between 2006 and 2010. Living with the local priest and his family, I had the chance to better understand how socio-political relations were negotiated between religiously defined groups on the local level. Living in Cairo 2004 to 2010, I followed the meetings of Christian and Muslim leaders and interviewed leaders from the Azhar, the Coptic Orthodox Church and the Muslim Brotherhood to better understand what official dialogue is. It became obvious how the above described features of society had crystallised into a discourse of MuslimChristian dialogue termed 'official dialogue', as one of the major discourses of dialogue in Egypt.

The negotiation of relations between Muslims and Christians was not consistently termed official dialogue on the local level, while this was the case to a larger extent on the national level. On the local level, the practices negotiating power dynamics was interchangeably called official dialogue, dialogue, meetings and visits. It is, however, clear that the socio-political dynamics on the local as well as the national level allowed for the Coptic Church to enter into relations with political authorities through what was termed official dialogue. It is the aim of this section of the article to describe official dialogue by showing how the local and national levels worked together to navigate the socio-political dynamics of Egypt.

Before moving to the village in 2006 , the priest told me that relations between Muslims and Christians in the village were very good compared to other parts of the region. This was, according to the priest, due to the fact that Muslims were visiting Christians in the churches, and Christians were visiting Muslims at the mosques, which was spoken of as a form of dialogue. Arriving at the village it was, however, evident that these visits did not encompass the average Christians and Muslims, but rather leaders, who would meet and discuss issues of importance to life in the villages. There were informal meetings prompted by ad hoc issues, but also more formal gatherings connected to national holidays, such as the Christmas celebration in January 2007. At this occasion the priest celebrated Christmas at the Church for the Christians, and then withdrew to his 
office, where I was invited to join a meeting between the priest and local Muslim dignitaries, who came to congratulate the priest, and through him the Christians, on their holiday. ${ }^{5}$ The meeting involved a feast and informal talk and joking, without breaching any faith issues.

When discussing the meeting with the priest afterwards, he explained that a meeting like this helped consolidate his influence through which he was able to maintain good relations between Muslims and Christians. With the absence of a functional judicial system and a neutral police force, local Muslim and Christian groups built security for their group by elevating their social influence in the area. The priest and his family explained that this was done partly by increasing the wealth of the group and by maintaining good relations with other influential groups.

The visits during the Christmas celebration could, however, also be understood simply as friendly visits without any further societal implications. To better understand this, I asked the priest how he viewed his relationship to the Muslims. He replied in the abstract about Muslims in general and explained that it was not possible to have Muslim friends as a Christian, as they could not be trusted. Muslims varied in his understanding from terrorists that are out to convert or eradicate Christians, to Muslims who tolerated Christians for the sake of maintaining positive business and generally peaceful relations - which was also the reason why he nursed relationships through various meetings. But he believed even the Muslims participating in these meetings secretly hated the Christians. While I stayed in the village, several Muslims with a seemingly very positive attitude towards the priest and Christianity had visited the Church. When I addressed this, the priest agreed that these were special and genuinely liked Christians, but he believed them to be Christians in their hearts, since Islam only can inspire hatred in his understanding. He only found very few of his Muslim acquaintances true friends, and it was clear that he saw most of his positive relations as a way of maintaining social cohesion and business relations, more than personal relations of friendship. As explained by Marilynn B. Brewer, the understanding of outgroups perceived as threatening influences the understanding of the individual members of the group (Brewer 2001). The understanding of Muslims as an amorphous, threatening outgroup was very clear in the interview with the priest; Muslims were understood as competitors and at times enemies, but the need for positive relations of the Christian minority community in the village pushed the priest to negotiate on behalf of the Christians. This in turn built relationships, which the priest would have to explain as an anomaly for this to make sense in relation to his general understanding of Muslims. The use of religion as a social delimiter

\footnotetext{
${ }^{5}$ I was invited to various meetings by the priest, without having any direct function at the meetings. It was my impression that my presence, being a Westerner, elevated the status of the priest.
} 
then becomes very clear in the narrative of the priest, as well as the understanding of dialogue as a tool to negotiate social relations.

The authority, status and wealth of the religious leaders in the local networks were especially important for these to represent their groups and consolidate their influence and security (Ismail 2006, 4852). It was therefore natural to the villagers, I spoke with, that the priest was also a thriving businessman with a focus on agriculture. I was invited to a meeting between the priest and an influential Christian businessman in Cairo, where the cultivation of the land was discussed as a specifically Christian issue. While the land would benefit the priest personally, it would also benefit Christians, as it would consolidate the influence of the priest to the benefit of the community. The influence of the local Christian community was furthermore discussed as promoting the lives of the Christians on the national level, as the combined status of the Christians led to a better position of negotiating for the national Church leaders, combining the local and global level of clientelism and corporatism. This will be discussed further when describing the national level.

The potential impact of the status of the priest on the local level became clear in December, 2006. The men of the local Christian bakery were working abroad leaving the shop and family vulnerable. A man from a Muslim family demanded his bread for free, but when this was denied him he returned with a larger group of men to take the bread and the valuables of the house by force. As the situation threatened to escalate, news spread and the Christians hurried home to protect their families. Following the incident, I discussed the matter with the priest and his family. According to the priest, they have relatively few of these incidents because of his standing and his good relations to Muslims leaders. His influence furthermore enabled him to engage the local police, who on his complaint arrived after the incident and arrested a male member of the family, who attacked the bakery. ${ }^{6}$ This helped ensure, according to a member of the family of the priest, that similar incidents would not happen again, as the influence of the priest was clear and future attacks would have consequences. The Christians, I spoke with in the area, categorised the assailants consistently as 'Muslims', and the issue as a MuslimChristian issue. The connections and influence the priest gained through meetings with religious representatives, termed official dialogue (although inconsistently), then enabled him to secure some level of what was felt as justice for the Christians in the village. This underlines the socio-political impact of the dialogue on the local level.

\footnotetext{
${ }^{6}$ Ismail explains how the police most often did not function as law keepers, but rather were seen as a threat in the less privileged areas of Egypt (Ismail 2006). The priest did, however, through his influence manage to use the police to make sure there was some consequence following the attack.
} 


\section{Official dialogue on the national level}

Official dialogue on the national level was manifest during my fieldwork and work in Egypt 2004-10 in at least three types of situations: meetings involving high level clergy, where issues of mutual interest were discussed, celebrations during Christmas and Ramadan, and meetings between clergy and government officials following violent incidents. My knowledge of these is primarily based on the media and interviews with a range of people involved in or critical towards official dialogue, as I only had the opportunity to join the high level dialogue meetings between international representatives of religious institutions. The third type of meeting clearly connected the local and national levels of official dialogue, as the national level directly interfered with the local, and as such it will be described more thoroughly.

Azharite Sheikhs and Coptic Orthodox clergy met regularly to discuss issues of mutual interest. It was generally agreed that the topics never involve faith articles, because it was believed, as an Azharite Sheikh involved in the meetings commented, that it will only lead to tensions and arguments. Across the people interviewed at this level of engagement between clergy, it was taken for granted that Christianity and Islam were different and incompatible as religions. They would instead meet to promote good relations between the faith communities, and discuss topics such as the position of children in the family, women in society, or how to address religious extremism. These topics were meant to galvanise relations against what would otherwise corrode them. Among the interviewees, the negative influences were found in satellite evangelists, a non-specified enemy in the West, and religious extremists, such as terrorists. The meetings were often televised, where Muslim and Christian clergy would sit together and publicly share what they had discussed in the private meeting. The meetings also resulted in projects, such as 'the reading for all' campaign initiated by the regime in 1992-1993 (Makari 2007; M. Guirguis and van Doorn-Harder 2011) and the recent 'Family House', which will be described later.

A symbol of positive relations between the Azhar and the Coptic Church was the celebration of the breaking of the fast during Ramadan and the celebration of Easter and Christmas, where the Coptic Church invited different Muslim officials (religious and otherwise) to join celebrations at the church (Galal 2009; Makari 2007, 85; M. Guirguis and van Doorn-Harder 2011, 168; Abu-Nimer, Khoury, and Welty 2007, 161). These meetings were started during the 1919 revolution (M. Guirguis and van Doorn-Harder 2011, 101), and participating in these consolidated the socio-political relations publicly. These events were signifiers in the construction of relations, incorporating the Church into the clientelist system of the country, according to a Coptic intellectual and activist interviewed. Especially 
the presence of the army - and not just government representatives shows that these meetings were part of a system, where religious influence was translatable into political influence, using Bourdieu's understanding of how symbolic capital brings together influences promoting social standing (Bourdieu and Wacquant 1992). The presence of regime and military representatives showed their support for the Church as a legitimate part of the country. The direct political implications of relations between the regime and the Coptic Church were furthermore sustained by the fact that the Coptic Church openly supported candidates during presidential elections in return for being part of the clientelist system that for example improved the chances of the Church for permissions to build and repair churches (a controversial issue) ${ }^{7}$ and established direct contact between Church leaders and governors during incidents between Muslims and Christians (Hassan 2003, 114).

The third manifestation of official dialogue took place after incidents between Muslims and Christians. Some incidents involving Muslims and Christians were particularly violent and gained national attention through the media. The case of the attack on Abu-Fana Monastery in Minya in May 2008 illustrates how local matters between Christians and Muslims involved Church leaders also from the national level in the resolving of the matter through extra-judicial reconciliation meetings. Previous to the attack there had been tensions between the Monastery and some Muslim families living in the area. The Muslim families felt that the continuous expansion of Monastery farm lands encroached on their possibilities. As I was informed living in the village, irrigating the desert was a delicate matter until the land was formally owned. Desert areas were owned by the State, but these could not be purchased before the buyer had proved intent of irrigation by actually irrigating the land. The period between starting irrigation and formally purchasing the land was therefore vulnerable, and tradition was to build a wall around the land being irrigated to lay claim to it. The attack was a reaction to the Monastery building a wall to lay claim to a piece of desert land. Around 60 armed Muslims attacked monks and labourers building the wall and destroyed buildings and property belonging to the Monastery, resulting in the death of a Muslim labourer and the injuring of several others. During the attack, the assailants furthermore kidnapped three Monks, subjected them to torture, and attempted to forcibly convert them to Islam (U.S. Department Of State 2008).

\footnotetext{
${ }^{7}$ A law was passed in 2005 permitting repairs without permit, but restrictions still applied, as repairs were restricted at the local level. According to the law, the objections of local Muslim residents and businesses were also expected to be taken into consideration (McCallum 2008, 72). Local authorities then often prohibited the building and repair of churches as they feared that this would lead to disorder and attacks from Muslims.
} 
The police arrived a few hours after the incident leading to the arrest of Muslims and Christians alike. It was accepted by the judiciary system that matters can be resolved through customary reconciliation meetings, even in cases such as this, which had the public - national and international - attention. The matter was initially resolved through reconciliation meetings, but the resolution eventually fell apart leaving no one responsible for the attack in the eyes of the law (U.S. Department Of State 2009). It is interesting to the topic of this article, who participated in the reconciliation meetings: Coptic businessmen (economic capital), the diocese (cultural or religious capital), a member of parliament, an attorney, the police (all representatives of social capital), and eventually Pope Shenouda (World Watch Monitor 2009). As such, all three of Bourdieu's types of capital (economic, cultural and social) are in play constructing a socio-political field (Bourdieu and Wacquant 1992), where religious (cultural) capital plays a significant role in determining social relations between religiously defined groups.

A Muslim Brotherhood lawyer interviewed was critical towards official dialogue, especially when it infringed on the legal system through reconciliation meetings. He formulated his concept of dialogue specifically against official dialogue, as he believed it was building the problems rather than helping them. The reconciliation meetings followed by public displays of unity between religious leaders circumvented the legal system were an expression of official dialogue, according to the lawyer, but they helped the culprits go free of any charges. Instead he believed dialogue should gather the religious leaders and thinkers to root out the negotiation between religious leaders in matters of law and promote a judicial system, where religion plays no role. As such, the lawyer was in line with many Human Rights Organisations, highlighting that the reconciliation meetings lead to impudence among the culprits, as they are not persecuted by law (Human Rights Watch 2012).

It should be clear, that religion was important as a cognitive 'border guard' separating Muslims and Christians. ${ }^{8}$ This cognitive identity marker was addressed with a discourse of national unity, superimposing the national identity on the religious identity. In the vocabulary of Tajfel (Postmes and Branscombe 2010), official dialogue was positioning the groups of Muslims and Christians in society. This positioning was, however, not addressing societal identity borders between Muslims and Christians: the 'border guard' was not contested to allow for Muslims and Christians to function also

8 Galal (Galal 2009, 227) talks about marriage as a border guard maintaining the distinction between societal groups, in this case Muslims and Christians, by maintaining the separation of blood relation. This is similar to Bourdieu's thoughts on "admission fees" without which people are not allowed to participate intimately with people of another social group (Bourdieu and Wacquant 1992, 107). 
on the more intimate level, such as marriage. This also explains why faith issues were not addressed: official dialogue was diplomacy between groups, but not an attempt to break down the barriers defining these groups as different social groups.

Official dialogue was thus a tool to promote the relations between societal groups delineated by religious belonging by making the ties official: official dialogue legitimised the regime cooperating with the Coptic Church through the authority of the Azhar. This was especially obvious after violent incidents, where high officials from the Coptic Church, the Azhar, and regime representatives would meet to sustain the discourse of national unity (Galal 2009). These displays of national unity between the high officials were, however, not only presenting a united front against violent extremists, but also against other opponents of the regime including moderate groups such as the Muslim Brotherhood: the religio-political dynamics not only tied specific groups of society closer together, but also as part of the act defined others as political opponents. The national dynamics of dialogue were thus not just between Islam and Christianity, but were rather influenced by a number of different societal groups influencing each other in multiple ways.

Like at the local level, official dialogue not only utilised the political dynamics of the country, but also helped sustain them. The political difference between Muslims and Christians was institutionalised through official dialogue. Furthermore, the senior clergy of the Azhar and the Coptic Orthodox Church gained influence in society by taking on the responsibility of representation, which included negotiating for their community in cases of conflict. This is likely to perpetuate existing power structures, including the system of clientelism.

\section{National unity or 'official nonsense'}

Central to official dialogue was the discourse of national unity (Galal 2009). Most of the interviewees talked about some form of national unity (Sedra 1999; Makari 2007, 33) that went beyond the obvious fact that Egyptian Muslims and Christians were Egyptians (McCallum 2008,62 ), even though they seemed aware of the obvious tensions in the country (Krämer 1998, 43). Some of these interviewees seemed unwilling to recognise the growing divide in Egyptian society and preferred not to mention the problems (Iskander 2012, 100), even though most of them were actively working with Muslim-Christian relations (Abu-Nimer, Khoury, and Welty 2007).

A major reason for the discourse of national unity is likely to be found outside religious belonging. As Ayubi points out, the Egyptian regime was to a large extent dependent on populism to maintain its legitimacy. This had been the case ever since Nasser. The basic 
argument of Ayubi is that the regime needed to establish some sort of unity in a country based on strong communal belonging to be able to rule this otherwise disparate society. To this end the discourse of national unity was an obvious remedy (Ayubi 2006, 209), and it was propagated through schools, media, official religion - and what was termed official dialogue by the people interviewed.

The discourse of national unity was often used in various efforts of dialogue, but also by many Muslims and Christians when addressing issues of discontent between religiously delimitated groups in Egypt. It often felt as amounting to treason to question this discourse. Even though the discourse of national unity was helpful in some situations, it also helped gloss over many of the real problems present between Muslims and Christians in Egypt (Galal 2009; Hansen 2015, chap. 3). Some of the televised meetings between Sheiks and priests would actively ignore the sectarian issues by reiterating the idea of unity as if it was actually, generally present. This meant that for some of the interviewees that dialogue was a precarious topic in as far as it meant admitting to problems based on religious difference. This changed with the 2011 revolution with the renegotiation of socio-political relationships, as will be the topic in the next section of the article, leading to more focus on dialogue as well as more sectarian incidents.

Official dialogue then publicly manifested unity between Muslims and Christians through the leaders of the communities. The effect of this was obvious when lay people said: "Muslims and Christians go and visit each other in their churches and mosques. There are no problems" without including themselves or other lay people physically in these meetings. But in the period, I did the interviews, many people were disillusioned with these dialogical manifestations as they did not see any tangible result in society, where tensions were growing - this led to one of the Muslim interviewees calling it 'official nonsense'. Among Christians the ties between the Church leadership and the state officials had also led to discontent as they felt continuously more pressed in society, while many felt that the Pope was not critical enough towards the regime and its lack of action against Muslim perpetrators and the general lack of social justice, according to the leader of a Coptic NGO with a focus on discrimination against Christians in Egypt.

Official dialogue can then be summed up as follows: the focus of official dialogue is to establish, maintain and/or improve relations between religious groups; official dialogue addresses societal relations to the exclusion of debates on articles of faith or religious practices; official dialogue is involved in the general structures of society by representing the two major religious groupings through diplomatic activities; official dialogue sustains the political ties between the Coptic Orthodox Pope and the President, strengthening the clientelist structures of Egyptian society; official dialogue is specific to the 
Egyptian social dynamics; official dialogue maintains religion as a 'border guard' between societal groups (in reality sustaining the legitimacy of religion as a societal delineator) and functions as diplomacy between these groups; while constructing relations between certain groups, official dialogue also helps define other groups as opponents; and finally, official dialogue sustains and benefits from the discourse of national unity - a political discourse that promotes unity among otherwise disparate social groups (Ayubi 2006, 209).

\section{Official dialogue following the 2011 Revolution}

The last section of the article will look at manifestations of official dialogue during the revolutionary period from 2011 until 2013. The focus is to trace manifestations of official dialogue in the revolutionary period. Official dialogue from before the revolution was carried into the revolutionary period, and used as a tool to negotiate relations between the entities in power, the Coptic Orthodox Church and the Azhar in the revolutionary process. This was clear when the Coptic Orthodox Church after the 2011 revolution invited different ruling entities to celebrations of great token value, such as the Christmas celebrations, with the aim of positioning themselves positively in Egyptian socio-politics. The political ties, essential to official dialogue were especially visible in the news coverage of the Pope very publicly supporting the military removing the Muslim Brotherhood President from power in 2013.

The revolution opened up debate generally in Egypt providing more freedom of speech and seriously questioned the discourse of national unity, which was the backbone of many of the prerevolutionary dialogue initiatives. The legitimate questioning of the discourse of national unity opened to a positive debate about the presence of Christians as Egyptian citizens and their hardships, the implications of which is the topic of this section, but it also opened to a critique of the influence of the Christians in socio-politics leading to more sectarian incidents, as has been discussed earlier in this article. It did, however, seem that the positive approach to Christian citizenship often was reactionary to the negative approach, sectarian incidents spawning discussions and Muslims making human chains around churches to protect them, or Facebook declarations of solidarity with the Christians following the Maspero incident in October 2011, but there were also initiatives aimed at changing the general Egyptian attitude, as will now be shown.

A major change was the fact that a number of NGOs, not specifically working with Muslim-Christian relations before, began to more openly address sectarian issues. Examples of this can be found with Nahdet el-Mahrousa and their Misriyati initiative and Hisham 
Mubarak Law Center and their Don't label Me initiative. Although not manifestations of official dialogue, they are interesting as they underline that the revolution brought a heightened awareness of sectarian issues and an inclination to work against them in Egyptian society during the revolution. A young Muslim activist working in Nahdet el-Mahrousa formulates it this way:

From my own experience working with Misriyati on diversity issues, I feel there is in general much more openness and willingness now after the revolution to talk about the injustices, discrimination, and related personal experiences in groups where both Muslims and Christians are present... (This applies on all levels, not only religious issues) although there certainly still is both 'shyness' and 'defensiveness' ... I guess the level of openness really depends on the group and the level of trust.

But she continues:

Two years later [after the 2011 revolution], a number of sectarian violence events have taken place (including the attack on the 'patriarchal' cathedral in Abassiyya), and the Islamist ideology is in power... I think now the general feel is one of 'fear'... and I think there is hardly any trust in the possibility of true dialogue... I think at this point the general population of Christians (as well as Muslims that do not have an Islamist ideology) see no significance to 'dialogue' as there is no trust.

The enthusiasm immediately following the revolution was challenged by the worsening situation after the revolution: the sectarian incidents increased, the financial situation was desperate, and political liberty was still needed. This underlines the growing awareness during the revolutionary period, which is the topic of this article.

The response to the elevated insecurity among Christians in Egypt varied greatly. The Coptic Orthodox Church as an institution seemed to lean towards official dialogue as before the revolution, but with changing allegiances according to the political climate, underlining the political use of official dialogue. In the beginning of the revolution the Coptic Orthodox Pope asked the Copts to not partake in the revolution, though many non-clergy Copts did not follow his request (M. Guirguis 2012, 512; Iskander 2012, 162). During the Christmas celebrations of the period, the Coptic Pope moved to accommodate the new political situation by using the same clientelist signifier as during the Mubarak regime: he invited the army and major political parties to participate in the Christmas celebration at the Coptic Orthodox Cathedral in Cairo, which traditionally has been, as described, a major signifier of peaceful relations in the official dialogue. The Muslim Brotherhood accepted the invitation in January 2012 and 2013, signalling willingness to political cooperation in the future, and by this, that they were open to maintain the 
clientelist mechanism of the Pope representing the Coptic Church as a political entity. The Salafist politicians failed to show at the Christmas celebrations - some of them even declaring it religiously unsound (Hauslohner 2012). In March 2012 the Supreme Guide of the Muslim Brotherhood followed up on the budding relations by visiting the Coptic Cathedral - as the first guide of the Muslim Brotherhood ever to do so officially - to wish the Pope well after his operations. Although the Muslim Brotherhood sent greetings through their homepage, they did not participate in the 2014 Christmas celebrations of the Coptic Church after the new round of political turmoil in 2013. It is not likely they were invited due to the changes in the political climate - the Muslim Brotherhood again being prohibited as an organisation. Instead, the interim president visited the Coptic Cathedral in the week before the Christmas celebrations and Coptic crowds cheered after the Christmas greeting of el-Sisi had been read.

With the death of Pope Shenouda in 2012, the newly elected Pope, Tawadros II, declared publicly that he would steer the Coptic Church clear of politics, but this does not seem to have been possible for him (Samaan 2012). This was especially clear during the 2013 revolution, where the Pope publicly supported the military removal of President Morsi from power, and in 2014 where the Pope openly promoted the presidency of el-Sisi. Many Copts were dependent on the patronage of the Coptic Orthodox Church and it was difficult for the new Pope to leave the worldly needs of his flock unheeded, as the Christians needed the same basic security as the rest of the population. The Pope was thus walking a tight rope between Copts demanding their democratic rights through demonstrations, the need for a place in the clientelist system by maintaining the discourse of national unity (i.e. within the legitimate circle of national belonging) through official dialogue, and an established hierarchy of power that could not easily be dismissed. The 2013 revolution did, however, ease the choice for the Coptic Pope, as most Christians frightened by the escalated violence targeting Christians were throwing their support behind the military, making it obvious for the Coptic Church to re-establish relations similar to those before the revolution.

It was not only the Coptic Pope who kept the interreligious discourses of the Mubarak era alive. Less than a month after the high profile attacks on the Copts in Maspero in 2011 involving the Egyptian military, the Grand Mufti of the Azhar denied any sectarian discrimination against Christians, maintaining the discourse of national unity. He instead blamed the turbulent times and a few Salafis.

A document released in June 2011 'al-Azhar Declaration on the Future of Egypt' underlined what the Azhar hoped to gain from the revolution, while at the same time committing themselves to democracy and religious dialogue: the Azhar wanted to establish itself as an independent, critical voice in Egyptian society (Bohlander 
2014). The document furthermore stated that religion cannot be used against the rights of other people - also underlining the rights of the Christians in Egypt. Many of the demands for institutional autonomy of the Azhar was rushed through by law during the interim reign of the SCAF (the Supreme Council of the Armed Forces) in January 2012, but the consequences of this is yet to be seen when the revolutionary dust settles as there was an outcry from the Muslim Brotherhood and a number of scholars (Brown 2012). However, with President el-Sisi demanding that the Azhar initiated a reformation of Islam in late 2014, the state control of the leadership of the Azhar seems intact.

The largest and potentially most influential post-revolutionary dialogue initiative was started by the Azhar in cooperation with the Coptic Church. The initiative was named 'Family House' (Baìt al 'Ayìla) and gathered artists, politicians, intellectuals, and religious leaders for workshops and debates on how to maintain positive relations between Muslims and Christians in Egypt. The initiative was already in the making before the revolution, as the Grand Sheikh of the Azhar called for the initiative after a church bombing in Alexandria in December 2010 and the first meeting took place just before the revolution on January the $17^{\text {th }} 2011$ - but the initiative first gained momentum after the revolution, as formulated by a Muslim interviewee:

When the revolution came and several sectarian clashes took place, the actual implementation and work of the initiative started to spread, you can say that the revolution affirmed the need of such initiatives and without it, it could have simply passed by like any other useless initiative.

The Grand Sheikh of the Azhar and the Coptic Pope took four year turns in heading the initiative underlining the cooperation between the Azhar and the Coptic Orthodox Church. According to a young Muslim woman from the dialogue environment, the initiative was inclusive and encompass, Azhar scholars, priests, journalists, theologians, famous actors, and prominent business men: different types of people and intellects are engaged in this initiative. The initiative was initially called the National Reconciliation Initiative, but was later named 'al Baīt al 'Ayīla' or 'The Family House'. A place where all Egyptians can meet based only on their citizenship, from all backgrounds, renouncing violence and sectarian clashes, spreading the message of peace and love. The initiative includes both Christians and Muslims for the purpose of educating, enlightening and delivering a correct image of each religion to the other.

The participants of the initiative were publicly visible through national television pushing for a more tolerant stance towards other religions, but the initiative also had access to a number of centers in 
the different governorates of the country, where youth met for week long retreats to get to know each other better despite religious differences.

The initiative seemed to be relatively low profile compared to the ruckus of the political turmoil during the revolution, but it seemed a sturdy initiative based on some of the more respected Muslim and Christian voices in contemporary Egypt. The initiative did not differ immensely from the pre-revolutionary official dialogue and was as such another example of dialogue based on the clientelist structures, but it did differ in important ways: it included a broader segment of Egypt's influential elite also encompassing for example artists and actors, which potentially pushed the initiative beyond the political use of official dialogue. This could be an indicator that the revolutionary period has opened both the non-religious and non-political environment to involve people from outside the traditional environment of official dialogue - and vice-versa. But it is still in 2015 too early to say, if this more open attitude towards MuslimChristian tension will endure.

\section{Conclusion}

The Egyptian socio-political structures have seemingly remained intact throughout the post-revolutionary period, this is witnessed not only in politics, but also in the official dialogue analysed in this article. The positions of the political players have, however, been negotiated leading to a more open public debate and the questioning of the discourse of national unity, fundamental to both dialogue initiatives and the glossing over of sectarian issues. This has led to elevated sectarian issues and a discussion of the societal position of the Christians in Egypt, but it has also led to some very interesting new dialogue initiatives by the people working with dialogue. One of the more interesting of these from official dialogue, Baît al 'Ayīla, is found in a cooperation between the Azhar and the Coptic Church involving also the media and prominent public figures. The size of the initiative and the involvement of for example artists and actors indicate are more open attitude towards the problems the Christian minority faces.

Based on observing the political situation in Egypt, it seems the open debate has been silenced. The interim governance of the military and the following President el-Sisi took steps to control the public debate, for example by shutting down a political satire show "The Show" commenting on Egyptian politics and hosted by Bassem Youssef - a hallmark of democratic blossoming during the revolution, and by introducing laws against unlicensed public gatherings to limit demonstrations, prohibiting journalism contradicting official statements of the regime, and strengthening the regime control over 
NGOs. It furthermore seems the open debate of sectarian issues has drowned in the dichotomisation between Islamists and non-Islamists, as the Islamists are blamed for any problems between Muslims and Christians, closing any further discussion about the very real problems for Christians ingrained in Egyptian society. While this ends the article on a rather bleak note, it is hoped that some of the initiatives started in the revolutionary period will continue to promote positive relations between Muslims and Christians in Egypt.

\section{Author biography}

Henrik Lindberg Hansen, originally a master of Theology, moved to Egypt in 2004, where he worked for six years with religious dialogue between Muslims and Christians for the Danish organisation, Danmission. In 2010 he started his doctoral work at School of Oriental and African Studies, University of London. After finishing the Ph.d., he moved back to Denmark where he rewrote the thesis into a book, which I.B. Tauris published in 2015 with the title ChristianMuslim Relations in Egypt: Politicis, Society and Interfaith Encounters. Currently, Henrik is working as an analyst for the government in Nuuk, Greenland.

\section{References}

Abdelrahman, Maha, 2004: "Divine Consumption: 'Islamic' Goods in Egypt.” In Cultural Dynamics in Contemporary Egypt, 69-78. Cairo: American University in Cairo Press.

Abercrombie, Nicholas, and Stephen Hill, 1976: "Paternalism and Patronage." The British Journal of Sociology 27 (4).

Abu-Nimer, Mohammed, Amal Khoury, and Emily Welty, 2007: Unity in Diversity: Interfaith Dialogue in the Middle East. Washington, D.C.: United States Institute of Peace Press.

Albrecht, Holger, 2007: "Political Opposition and Authoritarian Rule in Egypt.” Tübingen University.

Aoudé, Ibrahim G., 2013: "Egypt: Revolutionary Process and Global Capitalist Crisis.” Arab Studies Quarterly 35 (3): 241-54.

Ayubi, Nazih N., 2006: Over-Stating the Arab State: Politics and Society in the Middle East. London: I. B. Tauris.

Bohlander, Michael, 2014: "Political Islam and Non-Muslim Religions: A Lesson from Lessing for the Arab Transition." Islam and Christian-Muslim Relations 25 (1). 
Bourdieu, Pierre, and Loïs J. D. Wacquant, 1992: An Invitation to Reflexive Sociology. Chicago: University of Chicago Press.

Brewer, Marilynn B., 2001: "Ingroup Identification and Intergroup Conflict: When Does Ingroup Love Become Outgroup Hate?” In Social Identity, Intergroup Conflict, and Conflict Reduction, 17-37. Oxford: Open University Press.

Brown, Nathan J., 2012: "Contention in Religion and State in PostRevolutionary Egypt.” Social Research 79 (2).

Galal, Lise Paulsen, 2009: "Minoritet, Medborger Og Martyr: En Minoritetsteoretisk Analyse Af Positioner Og Fortællinger Blandt Ortodokse Koptere I Egypten.” http://www.ruc.dk/. (Accessed 21 Sep. 2015).

Galal, Lise Paulsen, 2012. "Coptic Christian Practices: Formations of Sameness and Difference." Islam and Christian-Muslim Relations 23 (1): 45-58.

Guirguis, Laure. Forthcoming. "The Brotherhood, the Copts, and the Egyptian Revolution: Identities and the Ballot Box. Game Over?” In Reconsidering Coptic Studies.

Guirguis, Magdi, 2012: "The Copts and the Egyptian Revolution: Various Attitudes and Dreams." Social Research 79 (2): 511-30.

Guirguis, Magdi, and Nelly van Doorn-Harder, 2011: The Emergence of the Modern Coptic Papacy: The Egyptian Church and Its Leadership from the Ottoman Period to the Present. Cairo: American University in Cairo Press.

Hansen, Henrik Lindberg, 2015: Christian-Muslim Relations in Egypt: Politics, Society and Interfaith Encounters. London: I. B. Tauris.

Hassan, Sana, 2003: Christians versus Muslims in Modern Egypt : The Century-Long Struggle for Coptic Equality. Oxford: Oxford University Press.

Hauslohner, Abigail, 2012: "Egypt's New Political Equation: Military, Muslim Brotherhood, Salafis.” Time Magazine.

Hulsman, Cornelis, 2013: "Christians Victims of the Growing Islamist Non-Islamist Divide; the Urgent Need for Peace and Reconciliation." Arab West Report.

Human Rights Watch, 2012: "Egypt: End Mubarak-Era Impunity for Sectarian Violence." 
https://www.hrw.org/news/2012/07/16/egypt-end-mubarak-eraimpunity-sectarian-violence. (Accessed 15 Oct. 2015).

Human Rights Watch, 2013: "Egypt: Mass Attacks on Churches." Human Rights Watch.

https://www.hrw.org/news/2013/08/21/egypt-mass-attacks-churches. (Accessed 21 Sep. 2015).

Iskander, Elizabeth, 2012: Sectarian Conflict in Egypt Coptic Media, Identity and Representation. London: Routledge.

http://www.academia.edu/895768/Sectarian_Conflict_in_Egypt_Copti c_Media_Identity_and_Representation.

(Accessed 21 Sep. 2015).

Ismail, Salwa, 2003: Rethinking Islamist Politics: Culture, the State and Islamism. London: I.B. Tauris.

Ismail, Salwa 2006: Political Life in Cairo's New Quarters: Encountering the Everyday State. Minneapolis: University of Minnesota Press.

Krämer, Gudrun, 1998: "Dhimmi or Citizen? Muslim-Christian Relations in Egypt." In The Christian-Muslim Frontier : Chaos, Clash, or Dialogue?, 33-44. London: I.B. Tauris.

Laclau, Ernesto, 2007: On Populist Reason. London: Verso.

Lemarchand, René, 1972: "Political Clientelism and Ethnicity in Tropical Africa: Competing Solidarities in Nation-Building." The American Political Science Review 66 (1): 68-90.

Makari, Peter E., 2007: Conflict \& Cooperation: Christian-Muslim Relations in Contemporary Egypt. Syracuse, N.Y.: Syracuse University Press.

McCallum, Fiona, 2008: "Muslim-Christian Relations in Egypt: Challenges for the Twenty-First Century." In Christian Responses to Islam: Muslim-Christian Relations in the Modern World. Manchester: Manchester University Press.

McNamara, Brendan, Evan Procknow, Joseph Soriero, Gregory Robins, Nico Fiorentino, Jenrette Nowaczynski, Maha Hamdan, Alan Cribb, and Graham Plaster, 2014: The Egypt Policy Playbook. The Intelligence Community LLC.

Postmes, T, and Nyla Branscombe: 2010: Rediscovering Social Identity: Key Readings. New York NY: Psychology Press. 
Samaan, Magdy, 2012: “A Politicized Papacy: Analysts Look at New Pope's Political Agenda.” Egypt Independent, 22 nov. edition.

Scott, Rachel, 2010: The Challenge of Political Islam: Non-Muslims and the Egyptian State. Stanford: Stanford University Press.

Sedra, Paul, 1999: "Class Cleavages and Ethnic Conflict: Coptic Christian Communities in Modern Egyptian Politics." Islam and Christian-Muslim Relations 10 (2): 219-33.

Singerman, Diane, 1997: Avenues of Participation: Family, Politics, and Networks in Urban Quarters of Cairo. Cairo: American University in Cairo Press.

Soliman, Samer, 2011: The Autumn of Dictatorship: Fiscal Crisis and Political Change in Egypt under Mubarak. Stanford, CA: Stanford University Press.

Sullivan, Denis, and Sana Abed-Kotob, 1999: Islam in Contemporary Egypt: Civil Society vs. the State. Boulder Colo.: L. Rienner.

U.S. Department Of State, 2008: “Egypt.” Report. http://www.state.gov/j/drl/rls/irf/2008/108481.htm. (Accessed 21 Sep. 2015).

U.S. Department Of State, 2009: "Egypt.” Report. http://www.state.gov/j/drl/rls/irf/2009/127346.htm. (Accessed 9 Nov. 2015).

Vogt, Kari, and Nelly van Doorn-Harder, 2004: Between Desert and City The Coptic Orthodox Church Today. Wipf \& Stock Pub.

Wickham, Carrie Rosefsky, 2002: Mobilizing Islam: Religion, Activism, and Political Change in Egypt. New York: Columbia University Press.

Wickham, Carrie Rosefsky, 2013: The Muslim Brotherhood: Evolution of an Islamist Movement. Princeton: Princeton University Press.

World Watch Monitor, 2009: "Two Egyptian Copts Re-Arrested in Abu Fana Murder." World Watch Monitor. https://www.worldwatchmonitor.org/2009/05-May/4091/. (Accessed 15 Oct. 2015). 